\title{
Article \\ Efficient Removal of Hexavalent Chromium from an Aquatic System Using Nanoscale Zero-Valent Iron Supported by Ramie Biochar
}

\author{
Xiangpeng Tan ${ }^{1}$, Muhammad Shaaban ${ }^{2,3}{ }^{-}$, Jianwei Yang ${ }^{1}$, Yajun Cai ${ }^{1}$, Buyun Wang ${ }^{1}$ and Qi-An Peng ${ }^{1, *}$ \\ 1 School of Environmental Engineering, Wuhan Textile University, Wuhan 430073, China; \\ xiangpengtan@163.com (X.T.); yangjw19991204@163.com (J.Y.); juniacai@163.com (Y.C.); \\ wbuyun@126.com (B.W.) \\ 2 Key Laboratory of Mountain Surface Processes and Ecological Regulation, Institute of Mountain Hazards \\ and Environment, Chinese Academy of Sciences, Chengdu 610041, China; shabanbzu@hotmail.com \\ 3 Department of Soil Science, FAS\&T, Bahauddin Zakariya University, Multan 60800, Pakistan \\ * Correspondence: pqa2002_@163.com
}

Citation: Tan, X.; Shaaban, M.; Yang, J.; Cai, Y.; Wang, B.; Peng, Q.-A.

Efficient Removal of Hexavalent Chromium from an Aquatic System Using Nanoscale Zero-Valent Iron Supported by Ramie Biochar. Nanomaterials 2021, 11, 2698. https:/ / doi.org/10.3390/nano11102698

Academic Editor: George Z. Kyzas

Received: 17 September 2021

Accepted: 10 October 2021

Published: 13 October 2021

Publisher's Note: MDPI stays neutral with regard to jurisdictional claims in published maps and institutional affiliations.

Copyright: (c) 2021 by the authors. Licensee MDPI, Basel, Switzerland. This article is an open access article distributed under the terms and conditions of the Creative Commons Attribution (CC BY) license (https:// creativecommons.org/licenses/by/ $4.0 /)$.

\begin{abstract}
In this study, ramie biochar (RBC) was used to activate nano zero-valent iron (nZVI) to enhance hexavalent chromium $(\mathrm{Cr}(\mathrm{VI}))$ removal. The best results were obtained at a pyrolysis temperature of $600{ }^{\circ} \mathrm{C}$, a biochar particle size of $<150 \mu \mathrm{m}$, and an iron to carbon ratio $=1: 1$. Under the optimal conditions, the removal of Cr(VI) by RBC600-nZVI (98.69\%) was much greater than that of RBC600 (12.42\%) and nZVI (58.26\%). Scanning electron microscopy (SEM), X-ray diffraction (XRD), Fourier transform infrared spectroscopy (FT-IR), and X-ray photoelectron spectroscopy (XPS) revealed that the reaction mechanism at the Fe and $\mathrm{Cr}$ interface was a multiple interaction mechanism with reduction dominated, adsorption, and co-precipitation simultaneously. The enhanced performance of RBC600-nZVI resulted from the effective dispersion of nZVI on the surface of RBC600, therefore increasing the adsorption activity sites. At the same time, RBC600 and nZVI exerted a synergistic influence on the composite structure, which jointly promoted the reduction reaction of $\mathrm{Cr}(\mathrm{VI})$ and removed more $\mathrm{Cr}(\mathrm{VI})$. This study shows that RBC-nZVI is a potentially valuable remediation material that not only provides a new idea for the utilization of ramie waste, but also effectively overcomes the limitations of nZVI, thus, achieving efficient and rapid remediation of $\mathrm{Cr}(\mathrm{VI})$.
\end{abstract}

Keywords: heavy metals; hexavalent chromium; nanoscale zero-valent iron; biochar; removal mechanism

\section{Introduction}

Environmental pollution of heavy metals is a devastating problem all over the world. Several industries release heavy metals into the environment. Chromium (Cr) is extensively used in industries for divergent purposes such as dye manufacturing, electroplating, paper production, leather tanning, and synthesis of paints [1,2]. Indecorous discarding and insufficient storage result in the entry of a huge amount of $\mathrm{Cr}$ into the environment and cause numerous chances of soil and water pollution in industrial areas [3,4]. Naturally, $\mathrm{Cr}$ in the environment is found in $\mathrm{Cr}(\mathrm{VI})$ and $\mathrm{Cr}(\mathrm{III})$ forms. The $\mathrm{Cr}(\mathrm{VI})$ is more concerned because of relatively more soluble, mobile, and toxic than $\mathrm{Cr}(\mathrm{III})[5,6]$. In addition, $\mathrm{Cr}(\mathrm{VI})$ has the potential to cause healthrelated problems ranging from minor skin irritation to lungs cancer [7]. Thus, the elimination of $\mathrm{Cr}(\mathrm{VI})$ from water resources is vital and an urgent environmental concern.

Scientists have devised the regulations related to limitations of heavy metals released into the environment, but novel efficient techniques are required to be investigated for the $\mathrm{Cr}(\mathrm{VI})$ removal from the aqueous environment. Nanometer zero-valent iron (nZVI), based on its distinctive characteristics such as highly reactive, and large surface area, has been profoundly used for the elimination of $\mathrm{Cr}$ from aqueous systems. Nevertheless, the reactivity of nZVI decreases over time due to its agglomeration and oxidization [8,9]. Researchers have devised various techniques to avoid such processes of iron (Fe) nanoparticles. The most commonly 
used techniques are utilizing inactive metals, surfactants, inorganic clay minerals, organic biomass materials, etc. [9]. Unfortunately, the modification of some of the above-mentioned materials may cause secondary pollution or reduce the reaction efficiency. Therefore, it is particularly important to prepare stable, dispersed, and environment-friendly modified nZVI $[10,11]$. Recently, the environment-friendly material biochar (BC) as the carrier material of nZVI has attracted extensive attention [12], not only because of its wide source and low cost, but also because of its high specific surface area, rich functional groups, and pores [13], which can make nZVI form on the surface of biochar without agglomeration and oxidation [9]. It is a technology with an application with the huge prospect of $\mathrm{Cr}$ elimination from the polluted environment systems. Currently, there have been several studies on the feasibility of removing $\mathrm{Cr}(\mathrm{VI})$ from aquatic solutions using biochar loaded with nZVI. The results indicate that BC-nZVI can act as a cost-effective adsorbent to remove $\mathrm{Cr}(\mathrm{VI})$ from wastewater. Some of the most recent works on BC-nZVI composites are summarized in Table 1. However, there are few studies on the functional properties of BC-nZVI composites [14]. The removal efficiency of loaded nZVI is a function of the surface area of loaded materials, iron content and exposed functional groups [14]. Therefore, it is important to optimize the surface of BC to achieve the maximum removal. The effects of preparation temperature, particle size and iron loading for the removal efficiency of $\mathrm{Cr}(\mathrm{VI})$ through $\mathrm{BC}$ application need further investigations. The production of Ramie (Boehmeria nivea; China grass, fiber yielding plant) is huge in China, and the cellulose content of ramie is very rich $[15,16]$. The by-products of cellulose pyrolysis can remove heavy metal ions in wastewater. Therefore, whether from the economic or environmental aspects, it has important application value to make biocarbon from ramie straw waste. The overall goal of this study was to increase the adsorption performance of $\mathrm{Cr}(\mathrm{VI})$ by ramie biochar (RBC) combined with nZVI (RBC-nZVI composite). The removal efficiency of $\mathrm{Cr}(\mathrm{VI})$ by RBC-nZVI composite under different preparation conditions was compared through batch adsorption experiments in the laboratory. The mechanism of $\mathrm{Cr}(\mathrm{VI})$ removal by RBC-nZVI composite was revealed by characterization and analysis using various advanced techniques. The specific research contents are as follows: (1) the effects of pyrolysis temperature, particle size, and iron loading on the physicochemical properties of RBC-nZVI composite were determined, (2) the adsorption characteristics of RBC-nZVI composite and the influence of $\mathrm{pH}$ and other environmental factors on $\mathrm{Cr}(\mathrm{VI})$ removal were determined, and (3) the mechanism of $\mathrm{Cr}(\mathrm{VI})$ removal by RBC-nZVI composite was elucidated.

Table 1. Removal of Cr(VI) from aqueous solutions by BC-nZVI composites.

\begin{tabular}{|c|c|c|c|}
\hline Biomass & Conditions & Removal Performance & Ref. \\
\hline $\begin{array}{l}\text { Sewage sludge and } \\
\text { sunflower seed shells }\end{array}$ & $\begin{array}{c}\mathrm{pH}=3 ; \mathrm{Cr}(\mathrm{VI})=50 \mathrm{mg} \mathrm{L}^{-1} ; \text { Dosage }=1.0 \mathrm{~g} \mathrm{~L}^{-1} \\
\text { Reaction time: } 90 \mathrm{~min}\end{array}$ & $95.00 \%$ & [17] \\
\hline Trametes suaveolens & $\begin{array}{c}\mathrm{pH}=2 ; \mathrm{Cr}(\mathrm{VI})=50 \mathrm{mg} \mathrm{L}^{-1} ; \text { Dosage }=5.0 \mathrm{~g} \mathrm{~L}^{-1} ; \\
\text { Reaction time: } 90 \mathrm{~min}\end{array}$ & $100 \%$ & [18] \\
\hline Oak wood & $\begin{array}{c}\mathrm{pH}=2 ; \mathrm{Cr}(\mathrm{VI})=50 \mathrm{mg} \mathrm{L}^{-1} ; \text { Dosage }=0.04 \mathrm{~g} ; \\
\text { Reaction time: } 12 \mathrm{~h}\end{array}$ & $99.9 \%$ & [19] \\
\hline Almond shell & $\begin{array}{c}\mathrm{pH}=2 ; \mathrm{Cr}(\mathrm{VI})=10 \mathrm{mg} \mathrm{L}^{-1} ; \text { Dosage }=0.08 \mathrm{~g} ; \\
\text { Reaction time: } 60 \mathrm{~min}\end{array}$ & $99.8 \%$ & [20] \\
\hline Flax straw & $\begin{array}{c}\mathrm{pH}=3 ; \mathrm{Cr}(\mathrm{VI})=100 \mathrm{mg} \mathrm{L}^{-1} ; \text { Dosage }=0.05 \mathrm{~g} ; \\
\text { Reaction time: } 24 \mathrm{~h}\end{array}$ & $186.99 \mathrm{mg} / \mathrm{g}$ & [21] \\
\hline $\begin{array}{l}\text { Woody biomass of } \\
\text { Prosopis juliflora }\end{array}$ & $\begin{array}{c}\mathrm{pH} \text { neutral; } \mathrm{Cr}(\mathrm{VI})=10 \mathrm{mg} \mathrm{L}^{-1} ; \text { Dosage }=0.02 \mathrm{~g} ; \\
\text { Reaction time: } 18 \mathrm{~h}\end{array}$ & $16.30 \mathrm{mg} / \mathrm{g}$ & [22] \\
\hline Sewage sludge & $\begin{array}{c}\mathrm{pH}=4 ; \mathrm{Cr}(\mathrm{VI})=50 \mathrm{mg} \mathrm{L}^{-1} ; \text { Dosage }=0.05 \mathrm{~g} ; \\
\text { Reaction time: } 24 \mathrm{~h}\end{array}$ & $31.53 \mathrm{mg} / \mathrm{g}$ & [23] \\
\hline Sewage sludge and the starch & $\mathrm{pH}=4 ; \mathrm{Cr}(\mathrm{VI})=30 \mathrm{mg} \mathrm{L}^{-1} ;$ Dosage $=1.5 \mathrm{~g} \mathrm{~L}^{-1}$; & $98.8 \%$ & [24] \\
\hline Rice straw & $\begin{array}{c}\mathrm{pH}=4 ; \mathrm{Cr}(\mathrm{VI})=20 \mathrm{mg} \mathrm{L}^{-1} ; \text { Dosage }=0.05 \mathrm{~g} ; \\
\text { Reaction time: } 24 \mathrm{~h}\end{array}$ & $40.0 \mathrm{mg} / \mathrm{g}$; & [25] \\
\hline Cornstalk & $\begin{array}{c}\mathrm{pH}=5 ; \mathrm{Cr}(\mathrm{VI})=10 \mathrm{mg} \mathrm{L}^{-1} ; \text { Dosage }=0.2 \mathrm{~g} \mathrm{~L}^{-1} ; \\
\text { Reaction time: } 4 \mathrm{~h}\end{array}$ & $17.8 \mathrm{mg} / \mathrm{g}$ & [6] \\
\hline Herb-residue & $\begin{array}{c}\mathrm{pH}=2 ; \mathrm{Cr}(\mathrm{VI})=20 \mathrm{mg} \mathrm{L}^{-1} ; \text { Dosage }=0.2 \mathrm{~g} \mathrm{~L}^{-1} ; \\
\text { Reaction time: } 4 \mathrm{~h}\end{array}$ & $98.71 \%$ & [26] \\
\hline
\end{tabular}




\section{Materials and Methods}

\subsection{Chemicals}

In order to perform experiments, we used the following reagents: ferrous sulfate heptahydrate $\left(\mathrm{FeSO}_{4} \cdot 7 \mathrm{H}_{2} \mathrm{O}\right)$, anhydrous ethanol $\left(\mathrm{C}_{2} \mathrm{H}_{6} \mathrm{O}\right)$, hydrochloric acid $(\mathrm{HCl})$, sodium hydroxide $(\mathrm{NaOH})$, sodium borohydride $\left(\mathrm{NaBH}_{4}\right)$, potassium dichromate $\left(\mathrm{K}_{2} \mathrm{CrO}_{4}\right)$, acetone $\left(\mathrm{C}_{3} \mathrm{H}_{6} \mathrm{O}\right)$, diphenylcarbazide $\left(\mathrm{C}_{13} \mathrm{H}_{4} \mathrm{~N}_{4} \mathrm{O}\right)$, phosphoric acid $\left(\mathrm{H}_{3} \mathrm{PO}_{4}\right)$, and sulfuric acid $\left(\mathrm{H}_{2} \mathrm{SO}_{4}\right)$ were instead purchased from Shanghai Guoyao reagent group, Shanghai, China. Analytical grade chemicals were used in the experiments. Whenever needed, ultra-pure water was used in the experiment.

\subsection{Preparation of Biochar}

Biochar was prepared by slow pyrolysis of biomass under closed anoxic conditions. The peeled waste ramie stalk was used as biomass raw material. Before pyrolysis, the biomass was washed with distilled water, and subsequently dried in an oven (GZX9030MBE, Shanghai Bosun Industrial Co., Ltd., Heifei, China) at $60{ }^{\circ} \mathrm{C}$ for $72 \mathrm{~h}$, and then milled into a powder $(<300 \mu \mathrm{m})$ in a grinding chamber (RS-FS1811, Hefei Royalstar Small Appliance Co., Ltd., Heifei, China). The crushed ramie straw was oven-dried at $60{ }^{\circ} \mathrm{C}$ for $12 \mathrm{~h}$ in a ceramic crucible. The biomass was placed in the vacuum tube furnace (1500XG.S.L., Hefei Kejing Material Tech. Co., Ltd., Heifei, China) and pyrolyzed at 300, 400, 500, 600 , and $700{ }^{\circ} \mathrm{C}$ under anoxic conditions for $2 \mathrm{~h}$. After that, raw biochar was treated with $1 \mathrm{~mol} / \mathrm{L} \mathrm{HCl}$ solution for $12 \mathrm{~h}$ and the effluent was washed with distilled water until the $\mathrm{pH}$ reached neutral. The $\mathrm{HCl}$-treated biochar was oven-dried at $60{ }^{\circ} \mathrm{C}$ for $12 \mathrm{~h}$ and, in order to prevent moisture contact, stored in a desiccator. The granules of biochar were crumbled and ground to make a powder using a mortar and pestle, and sieved for obtaining the following particle sizes: 300-600 $\mu \mathrm{m}, 150-300 \mu \mathrm{m}, 75-150 \mu \mathrm{m}$, and $<75 \mu \mathrm{m}$.

\subsection{Preparation of $n Z V I$}

The nanoscale zero-valent iron (nZVI) was prepared using the method of liquidphase reduction [27]. Simply, an aqueous solution of $\mathrm{NaBH}_{4}$ was added into $\mathrm{FeSO}_{4} \cdot 7 \mathrm{H}_{2} \mathrm{O}$ solution. The ferric ion was reduced resulting an nZVI as shown in the Equation (1):

$$
\mathrm{Fe}^{2+}+2 \mathrm{BH}_{4}^{-}+6 \mathrm{H}_{2} \mathrm{O} \rightarrow \mathrm{Fe}^{0}+2 \mathrm{~B}(\mathrm{OH})_{3}+7 \mathrm{H}_{2} \uparrow
$$

Briefly, we dissolved $\mathrm{FeSO}_{4} \cdot 7 \mathrm{H}_{2} \mathrm{O}(0.05 \mathrm{M})$ in the ethanol and anaerobic water solution (solution of anaerobic ethanol and anaerobic water was prepared with 1:4, $v / v$ ratio) contained in a three-neck flask. After that, stirring was performed with ambient $\mathrm{N}_{2}$ gas for $30 \mathrm{~min}$. The $\mathrm{NaBH}_{4}(0.2 \mathrm{M})$ was dissolved in ultrapure water using a separating funnel, and gently poured in the $\mathrm{FeSO}_{4} \cdot 7 \mathrm{H}_{2} \mathrm{O}$ solution. Afterwards, vigorous stirring of the mixture was performed for $1 \mathrm{~h}$ under anaerobic conditions $\left(\mathrm{N}_{2}\right.$ gas was used to develop anaerobic conditions) during the entire procedure to avoid the oxidation process of nanoparticles. Following the completion of the reaction, the precipitates of nZVI were rinsed using anoxic ultrapure water and anhydrous ethanol three times for the removal of excessive $\mathrm{NaBH}_{4}$. The nZVI precipitates were dried following the method of vacuum-drying-chamber for $12 \mathrm{~h}$ and subsequently kept in a vacuum drying container.

\subsection{Preparation of RBC-nZVI}

RBC-nZVI was synthesized according to the method described by Su et al. [28] with some modifications. Initially, ferrous sulfate $\left(\mathrm{FeSO}_{4} \cdot 7 \mathrm{H}_{2} \mathrm{O}\right)$ and biochar were pooled in $75 \mathrm{~mL}$ of anaerobic water (adjusted $\mathrm{pH}$ of the solution was 4.0) and agitated on an electric shaker at $150 \mathrm{rpm}$ for $24 \mathrm{~h}$ at $25^{\circ} \mathrm{C}$. After that, the solution was moved into a three-neck round bottom flask which already had a volume of $25 \mathrm{~mL}$ of ethanol. The $\mathrm{N}_{2}$ gas was purged into the solution, while concurrently, a robust stirring was performed for $30 \mathrm{~min}$ to remove dissolved $\mathrm{O}_{2}$. Then, $\mathrm{NaBH}_{4}$ solution was mixed dropwise into the slurry under strong stirring conditions. The fabrication process is shown in Figure 1. The prepared 
products were used for subsequent characterization and experiments.

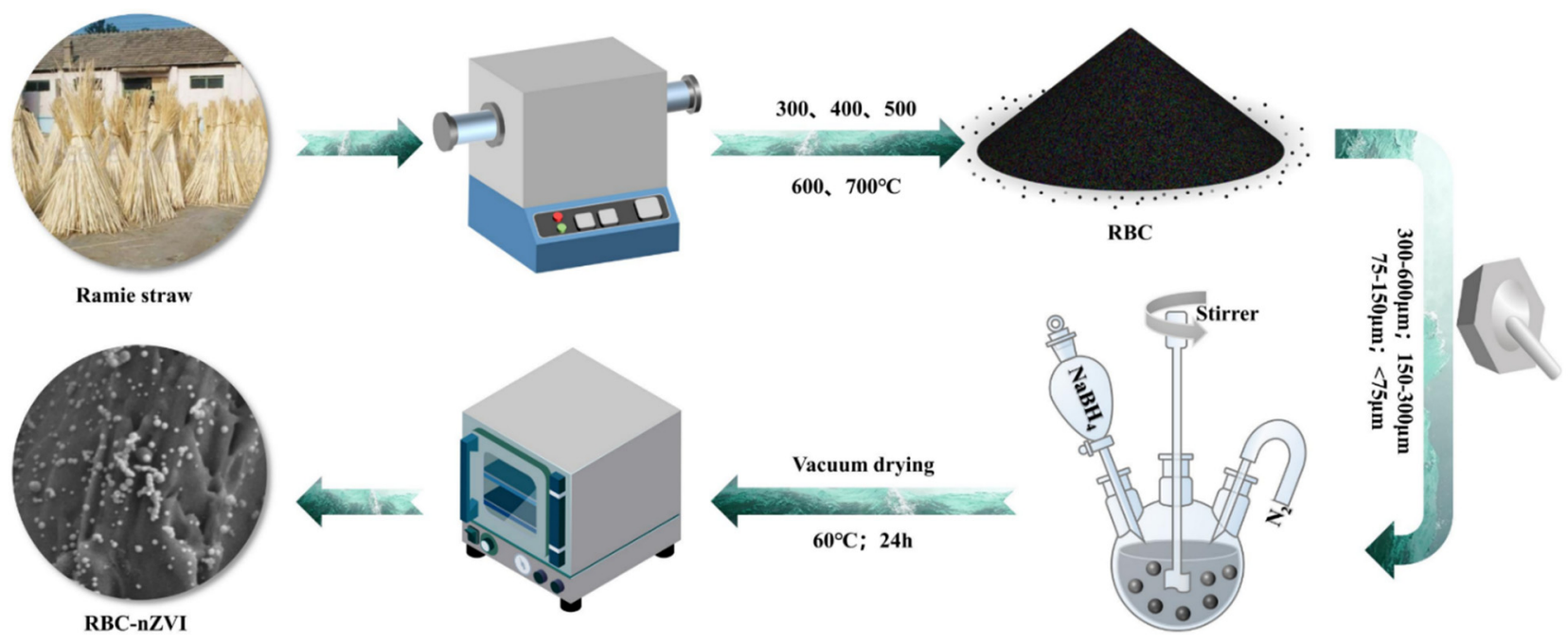

Figure 1. Preparation process of RBC/nZVI composite.

\subsection{Characterization}

The characterization of material was carried out by adopting several techniques including Scanning Electron Microscopy (SEM, Zeiss Sigm 300, Los Angeles, CA, USA), Fourier Transform Infrared (FTIR, 6700, Therm. Scient. Nicolt, Steinheim, Germany), X-ray powder diffraction (XRD, D8 Brukr Adv., Oberkochen, Germany), and X-ray photoelectron spectroscopy (XPS, Therm. Scient. K-Alpha, Boston, MA, USA). The dispersion, surface morphology, microstructure of nanoparticles were tested by SEM. To analyze the FTIR spectra, NZVI and biochar were mixed and powder of potassium bromide $(\mathrm{KBr})$ was added with a mass ratio of $1 / 100$. A wave number ranging from 400 to $4000 \mathrm{~cm}^{-1}$ was noted at a resolution of $4 \mathrm{~cm}^{-1}$ and 64 inter-ferogram. The XRD spectra were obtained to analyze the crystal structure of nZVI and biochar. The XRD analysis had the capability to identify at a scanning speed of $5 \mathrm{~min}^{-1}$ ranging from 5 to 80 . The identification of chemical composition and chemical valent changes before and after $\mathrm{Cr}(\mathrm{VI})$ remediation was validated on $\mathrm{X}$-ray photoelectron spectroscopy.

\subsection{Batch Experiments}

\subsubsection{Influence of Preparation Conditions}

For the comparison of the effects of different RBC and RBC-nZVI on $\mathrm{Cr}(\mathrm{VI})$ elimination from aqueous solution, the reaction for the removal of $\mathrm{Cr}(\mathrm{VI})$ was conducted in a series of conical flasks. The reaction system was sampled and analyzed at 0, 5, 10, 20, 30, 40, 50, and $60 \mathrm{~min}$. The content of $\mathrm{Cr}(\mathrm{VI})_{\mathrm{e}}$ was analyzed, and the $\mathrm{Cr}(\mathrm{VI})$ elimination was was calculated using Equation (2):

$$
\mathrm{Cr}(\mathrm{VI}) \text { removal }=\mathrm{Cr}(\mathrm{VI})_{0}-\mathrm{Cr}(\mathrm{VI})_{\mathrm{e}} / \mathrm{Cr}(\mathrm{VI})_{0}
$$

A volume of $100 \mathrm{~mL}$ of $20 \mathrm{mg} / \mathrm{L} \mathrm{Cr}(\mathrm{VI})$ solution was taken into each conical flask $(250 \mathrm{~mL})$, and then $1 \mathrm{~g} / \mathrm{L}$ of RBC-nZVI particles was added into each conical flask. The reaction was carried out on a constant temperature oscillator with a rotating speed of $150 \mathrm{r} / \mathrm{min}$ at $25^{\circ} \mathrm{C}$. The samples were taken at regular intervals and separated through a polytetrafluoroethylene membrane $(0.22 \mu \mathrm{m})$. The $\mathrm{Cr}(\mathrm{VI})$ concentration was analyzed by diphenyl carbazide spectrophotometry [29].

\subsubsection{Influence of Environmental Factors}

To explore the effects of different reaction conditions on the removal of $\mathrm{Cr}(\mathrm{VI})$ from aqueous solution, for example, initial $\mathrm{Cr}(\mathrm{VI})$ concentration $(\mathrm{mg} / \mathrm{L})$, material dosage $(\mathrm{g} / \mathrm{L})$, reaction temperature $\left({ }^{\circ} \mathrm{C}\right)$, and initial $\mathrm{pH}$ of the solution, the optimal conditions for the 
reaction were determined. In the batch experiment, the dosage of the composite was set as $0.5,0.8,1.0,1.3$, and $1.5 \mathrm{~g} / \mathrm{L}$, and the initial concentration of $\mathrm{Cr}(\mathrm{VI})$ was $20 \pm 1 \mathrm{mg} / \mathrm{L}$; other reaction conditions remained unchanged. In the batch experiment, the initial concentration of $\mathrm{Cr}$ (VI) was set to $10 \pm 1,20 \pm 1,40 \pm 1,60 \pm 1,80 \pm 1 \mathrm{mg} / \mathrm{L}$, whereas the dosage of the composite was $1.0 \mathrm{~g} / \mathrm{L}$, and other reaction conditions remained unchanged. In the batch experiment to explore the effect of reaction temperature, the reaction temperature was selected as $25,35,45,55^{\circ} \mathrm{C}$, the dosage of composite was $1.0 \mathrm{~g} / \mathrm{L}$, and other reaction conditions remained unchanged. In order to explore the effect of the initial $\mathrm{pH}$ of the solution, the initial $\mathrm{pH}$ of the solution was set as 3,5,6,7, and 9, the dosage of composite material was $1.0 \mathrm{~g} / \mathrm{L}$, and the original concentration of $\mathrm{Cr}(\mathrm{VI})$ was $20 \pm 1 \mathrm{mg} / \mathrm{L}$, other reaction conditions remained unchanged. Two parallel control groups were set for the above reactions to explain the error range in the reaction process.

\section{Results and Discussion}

\subsection{The Characterization of Biochar and Biochar-Supported $n Z V I$ \\ 3.1.1. SEM}

The morphology and structure of the nZVI and RBC600-nZVI were identified through SEM analysis (Figure 2). The particles of nZVI produced by liquid-phase reduction had the size of nanometer scale, were spherical in shape, forming protruding chain-like aggregates (Figure 2a,b), which was primarily because of the interaction of the surface effects and the static magnetic forces. The analysis of the nano-measurer displayed that the average size of $\mathrm{nZVI}$ was $64.95 \pm 19.17 \mathrm{~nm}$. We confer that enhanced dispersion and smaller size of $\mathrm{nZVI}$ particles resulted due to the amalgamation of RBC (Figure 2c,d). The mean particle diameters were $51.72 \pm 15.86 \mathrm{~nm}$ for RBC600-nZVI. Furthermore, there was not any prominent aggregation on RBC600-nZVI. The results show that the particles of nZVI were markedly immobilized on the surface of RBC.

(a)

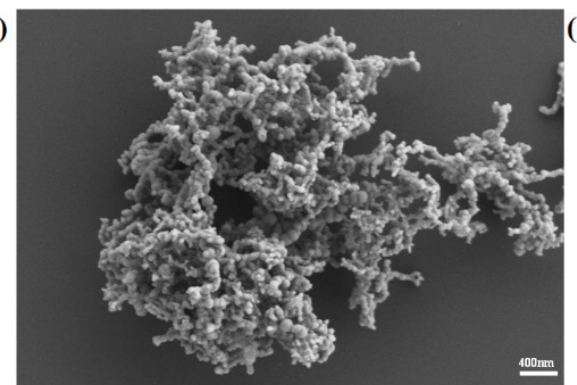

(d)

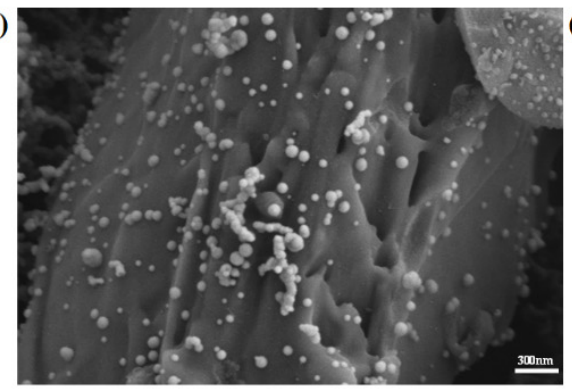

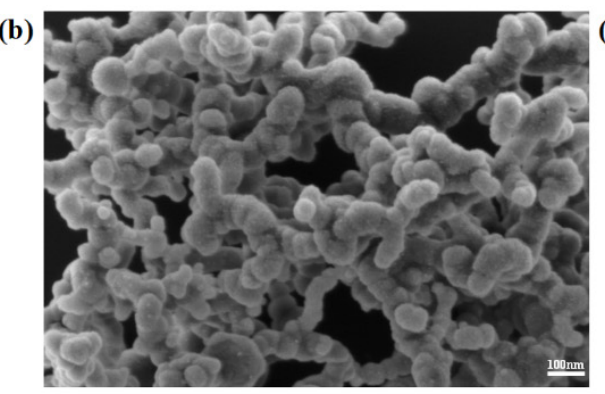

(e)

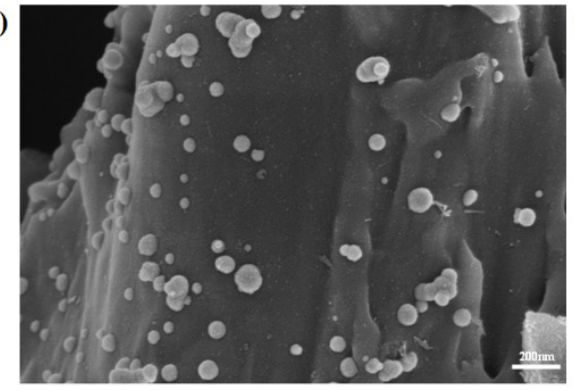

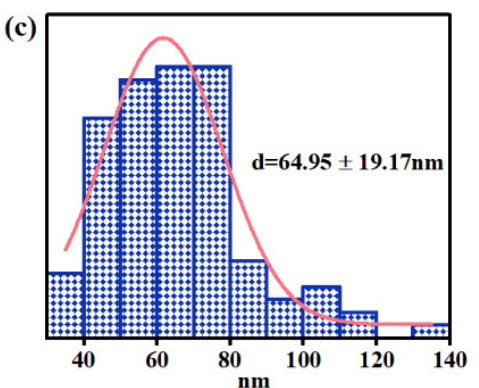

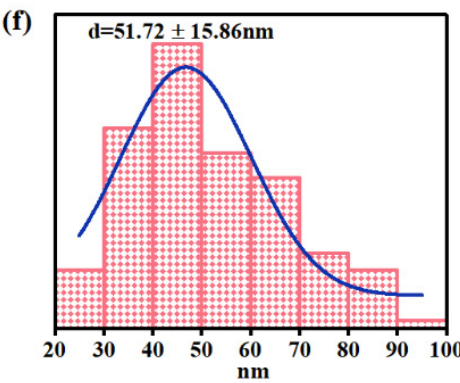

Figure 2. SEM images and corresponding particle size distribution of nZVI (a-c) and RBC600-nZVI (d-f). The insertion: the nanoparticle size distribution, calculated with Nano Measurer and 100 particles were selected for each sample.

\subsubsection{FTIR}

The functional groups in RBC600 and RBC600-nZVI were determined by implementing an FT-IR technique (Figure 3a). An absorption peak obviously occurred at $3440 \mathrm{~cm}^{-1}$, which ranged between 3200 and $3500 \mathrm{~cm}^{-1}$, representing the intermolecular stretching of the hydrogen $(\mathrm{H})$ bonding and thereby representing the peak of the hydroxyl group [30]. 
Markedly, the hydroxyl groups of RBC600-nZVI were ominously augmented as compared with the RBC600, which supported relatively more adsorption pockets for $\mathrm{Cr}(\mathrm{VI})$ adsorption [31]. There was a sharp peak at $2924 \mathrm{~cm}^{-1}$ which contributed to $\mathrm{C}-\mathrm{H}$ stretching vibration (- $\mathrm{CH}_{3}$ or $-\mathrm{CH}_{2}$ group) $[30,32]$. The band around $1115 \mathrm{~cm}^{-1}$ was relevant to the group pertaining to the $\mathrm{C}-\mathrm{O}$ stretching vibrations [3]. The FT-IR spectrum pertinent to RBC600-nZVI presented the typical peaks of iron (Fe) species, comprising the bands of Fe-O stretching vibration at $\sim 524 \mathrm{~cm}^{-1}$ [1]. In addition, the peak of $693 \mathrm{~cm}^{-1}$ displayed the occurrence of Fe-OOH [4]. In comparison to RBC600, the RBC600-nZVI reflected two additional absorption peaks at 1341 and $1625 \mathrm{~cm}^{-1}$, indicating - $\mathrm{COOH}$ and $\mathrm{C}=\mathrm{O}$, respectively $[5,33]$.

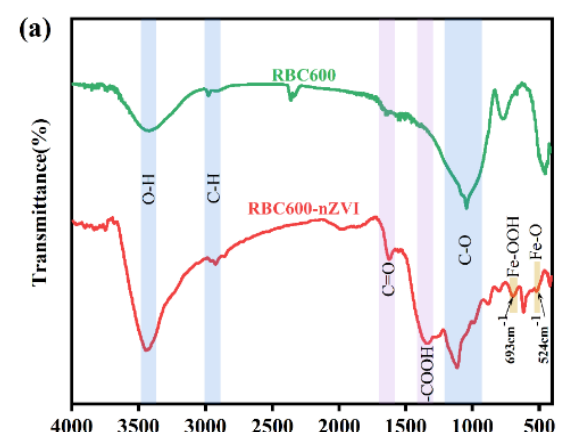

Wavenumbers $\left(\mathrm{cm}^{-1}\right)$

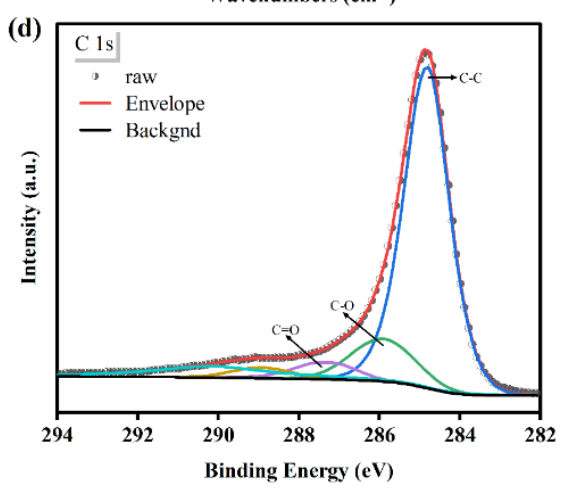

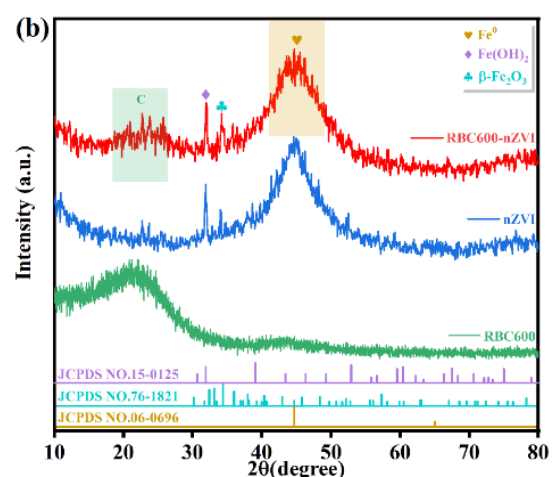

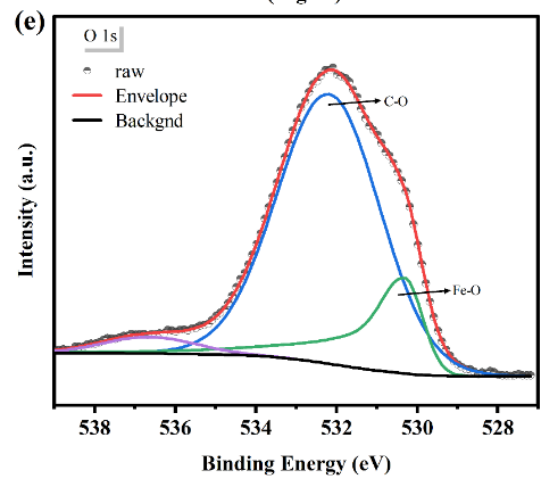

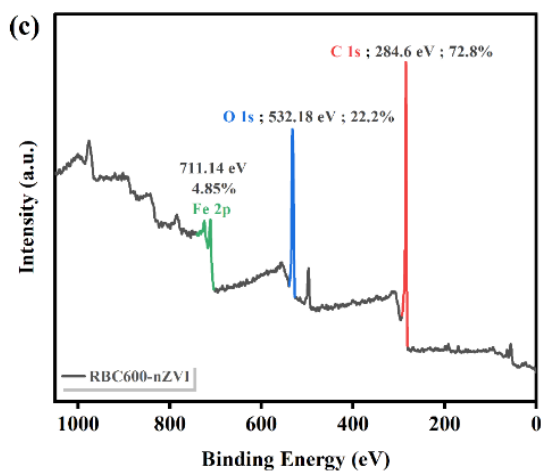

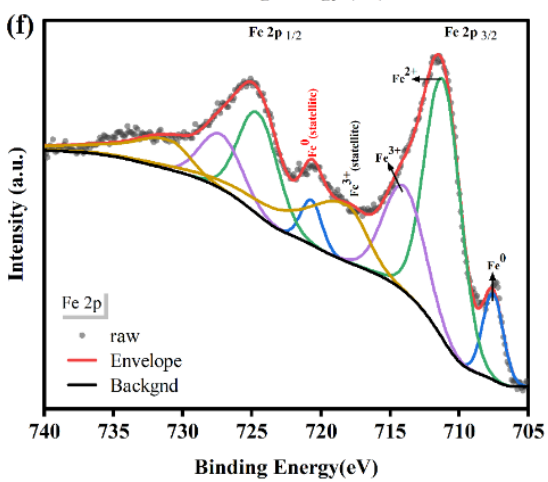

Figure 3. FTIR spectra pertaining to the RBC600 and RBC600-nZVI (a); XRD patterns of RBC600, nZVI, and RBC600-nZVI (b); XPS spectra of RBC600-nZVI prior to reaction with $\mathrm{Cr}(\mathrm{VI})$ : Full survey (c), C 1s (d), O 1s (e), and Fe 2p (f) binding state levels.

\subsubsection{XRD}

The RBC600, nZVI, and RBC600-nZVI particles were characterized by XRD (Figure 3b). The RBC600 displayed a diffraction peak at $22.0^{\circ}$ [4]. The sample of nZVI exhibited a principal peak at $44.7^{\circ}$ attributing to (110) planes of a- $\mathrm{Fe}^{0}$ (JCPDS Number: 06-0696) [7], the peaks at $31.9^{\circ}$ and $34.4^{\circ}$ pertained to the planes of (113) of $\mathrm{Fe}(\mathrm{OH})_{2}$ (JCPDS Number: 15-0125) and (113) of $\beta-\mathrm{Fe}_{2} \mathrm{O}_{3}$ (JCPDS Number: 76-1821), respectively, which is a characteristic core-shell structure of nZVI [34]. For the RBC600-nZVI, the peaks at $22^{\circ}, 31.9^{\circ}, 34.4^{\circ}$, and $44.7^{\circ}$ were observed, displaying an effective production of nZVI on the surface of RBC600 [19].

\subsubsection{XPS}

The electronic valence of the elements in the RBC600-nZVI were examined through XPS [1]. Full survey spectrum of RBC600-nZVI showed the peaks at $284.8 \mathrm{eV}$ pertaining to $\mathrm{C}, 532.2 \mathrm{eV}$ related to $\mathrm{O}$, and $711.1 \mathrm{eV}$ pertinent to Fe elements (Figure $3 \mathrm{c}$ ). The ratio of $\mathrm{C}$, $\mathrm{O}$, and Fe elements to total surface iron atoms was about $72.8,22.2$, and $4.85 \%$, respectively. Figure $3 \mathrm{~d}$ shows peaks at 284.8, 285.9, 287.3, $288.9 \mathrm{eV}$, and $290.2 \mathrm{eV}$, corresponding to $\mathrm{C}-\mathrm{C}$, $\mathrm{C}-\mathrm{O}, \mathrm{C}=\mathrm{O}$, and $\mathrm{O}-\mathrm{C}=\mathrm{O}$, and $\mathrm{C}-\mathrm{COOR}$, respectively. After the deconvolution of $\mathrm{C} 1 \mathrm{~s}, \mathrm{C}-\mathrm{C}$, $\mathrm{C}-\mathrm{O}, \mathrm{C}=\mathrm{O}, \mathrm{O}-\mathrm{C}=\mathrm{O}$, and $\mathrm{C}-\mathrm{COOR}$ were found to account for $71.54,12.59,8.09,4.92$, and $2.85 \%$, respectively. Figure 3 e represents the $\mathrm{O} 1$ s spectra of XPS, which comprised peaks at 
530.3 and $532.2 \mathrm{eV}$ displaying $\mathrm{Fe}-\mathrm{O}$ and $\mathrm{C}-\mathrm{O}$, respectively. After the deconvolution of $\mathrm{O} 1 \mathrm{~s}$, Fe-O and $\mathrm{C}-\mathrm{O}$ were found to account for 77.91 and $17.87 \%$, respectively. The XPS analysis confirmed that Fe supported on RBC600-nZVI exists in different oxidation states [21]. The Fe $2 p$ spectrum of the material revealed having eight divergent peaks (Figure $3 \mathrm{f}$ ). The peaks having binding energies of $727.2 \mathrm{eV}, 724.5 \mathrm{eV}$, and $720.69 \mathrm{eV}$ reflected the Fe 2p1/2, while the peaks having binding energies of $713.97 \mathrm{eV}, 711.14 \mathrm{eV}$, and $707.55 \mathrm{eV}$ were pertinent to the Fe 2p3/2. The binding energy of the Fe $2 \mathrm{p} 1 / 2$ and Fe $2 \mathrm{p} 3 / 2$ at $727.23 \mathrm{eV}$ and $713.97 \mathrm{eV}$ corresponded to trivalent Fe. The binding energy of the Fe 2p1/2 and Fe 2p3/2 at $724.52 \mathrm{eV}$ and $711.14 \mathrm{eV}$ corresponded to divalent Fe. The peak at $707.6 \mathrm{eV}$ was related to $\mathrm{Fe}^{0}$, indicating that the existence of $\mathrm{Fe}^{0}$ species on the RBC600-nZVI surface. The peak area ratio of $\mathrm{Fe}^{0}: \mathrm{Fe}(\mathrm{II}): \mathrm{Fe}(\mathrm{III})$ was 1: 2.4: 2.5. This denotes that the nZVI surface was certainly wrapped with an oxide layer having a thickness of $<10 \mathrm{~nm}[35,36]$. Nevertheless, earlier studies illustrated that the surface oxide layer possesses several active adsorption sites [37], which is supportive of the adsorption of $\mathrm{Cr}(\mathrm{VI})$ [38].

\subsection{Removal of $\mathrm{Cr}(\mathrm{VI})$ by $\mathrm{RBC}$}

The removal performance of $\mathrm{RBC}$ at different pyrolysis temperatures is shown in Figure 4a. The treatment effect of RBC had no significant $(p<0.05)$ difference pyrolyzed at $400,500,600$, and $700{ }^{\circ} \mathrm{C}$. The treatment effect of RBC600 and RBC700 was only $2.54 \sim 3.28 \%$ higher than RBC300. At $60 \mathrm{~min}, \mathrm{Cr}(\mathrm{VI})$ removal rates by RBC pyrolyzed at $300-700{ }^{\circ} \mathrm{C}$ were $9.88,10.92,11.32,12.42$, and $13.16 \%$, respectively. The RBC600 was selected to study the impact of particle size on $\mathrm{Cr}(\mathrm{VI})$ elimination by RBC (Figure $4 \mathrm{~b})$. During the whole reaction period, there were no significant $(p<0.05)$ differences for the removal efficiency of $\mathrm{Cr}(\mathrm{VI})$ by biochar with different particle sizes. In consistence with the literature, the above results displayed that $\mathrm{Cr}(\mathrm{VI})$ elimination by $\mathrm{RBC}$ was insignificant.
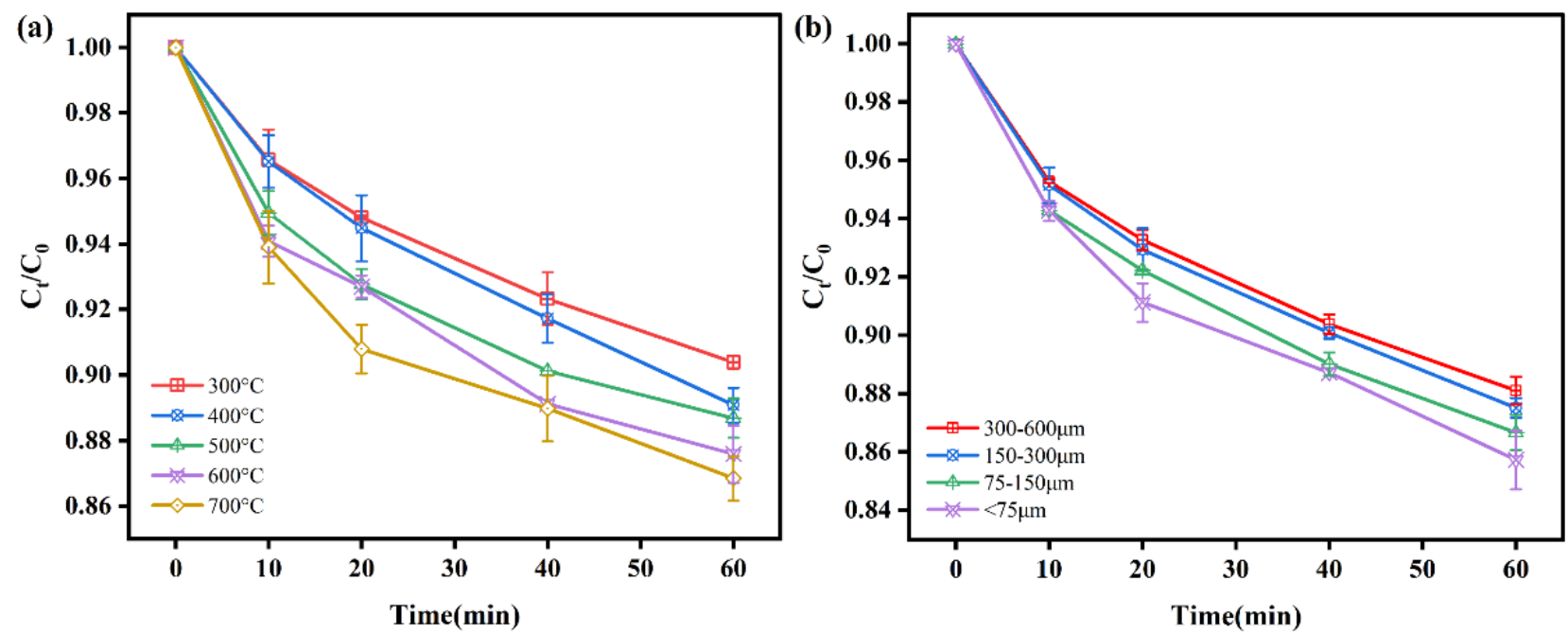

Figure 4. $\mathrm{Cr}(\mathrm{VI})$ removal by RBC prepared at different pyrolysis temperatures (a); RBC with different particle sizes (b); experimental conditions: initial $\mathrm{Cr}(\mathrm{VI})$ concentration $20 \mathrm{mg} / \mathrm{L}, \mathrm{RBC}$ dosage $0.5 \mathrm{~g} / \mathrm{L}, \mathrm{T}=25^{\circ} \mathrm{C}, \mathrm{pH}=5$.

\subsection{Effects of Preparation Conditions on Cr(VI) Removal}

Biochar produced at different pyrolysis temperatures (RBC300-RBC700) were utilized to support nZVI particles for Cr(VI) removal. The RBC300-nZVI, RBC400-nZVI, RBC500-nZVI, RBC600-nZVI, and RBC700-nZVI displayed great efficacy for Cr(VI) removal (Figure $5 \mathrm{a}$ ). The $\mathrm{Cr}(\mathrm{VI})$ removal was quick during the first $5 \mathrm{~min}$, whereas the $\mathrm{Cr}(\mathrm{VI})$ removal performance of RBC300-nZVI RBC700-nZVI after 20 min was almost the same (around $100 \%$ ). The fastest removal efficacy of $90.44 \%$ was attained with RBC600-nZVI at $5 \mathrm{~min}$, which was significantly higher than other treatments $(p<0.05)$. Moreover, Table 1 shows the removal ability of other biochar-modified nano-zero-valent iron materials for 
$\mathrm{Cr}(\mathrm{VI})$. Compared with them, the removal time of RBC600-nZVI is short and the removal efficiency is high. Therefore, RBC600 was selected to explore the removal effect of $\mathrm{Cr}(\mathrm{VI})$ by nZVI supported by RBC with different particle sizes. Figure $5 b$ shows the performance of the four types of modified biochars (300-600 $\mu \mathrm{m}, 150-300 \mu \mathrm{m}, 75-150 \mu \mathrm{m}$, and $<75 \mu \mathrm{m}$ ) for the removal of $\mathrm{Cr}(\mathrm{VI})$. The results displayed that the effect of nZVI treatment with RBCs of 300-600 microns (71.96\% at $60 \mathrm{~min})$ was significantly lower than that of the other three treatments (all above 98\%) $(p<0.05)$, among which RBCs with a particle size of less than 75 microns loaded nZVI works best, reaching the peak first. This may be because the smaller biochar particles $(<150 \mu \mathrm{m})$ prevented the aggregation and oxidation of iron on the surface, and therefore the increased particle size led to the passivation of the composite due to aggregation and oxidation of iron particles.
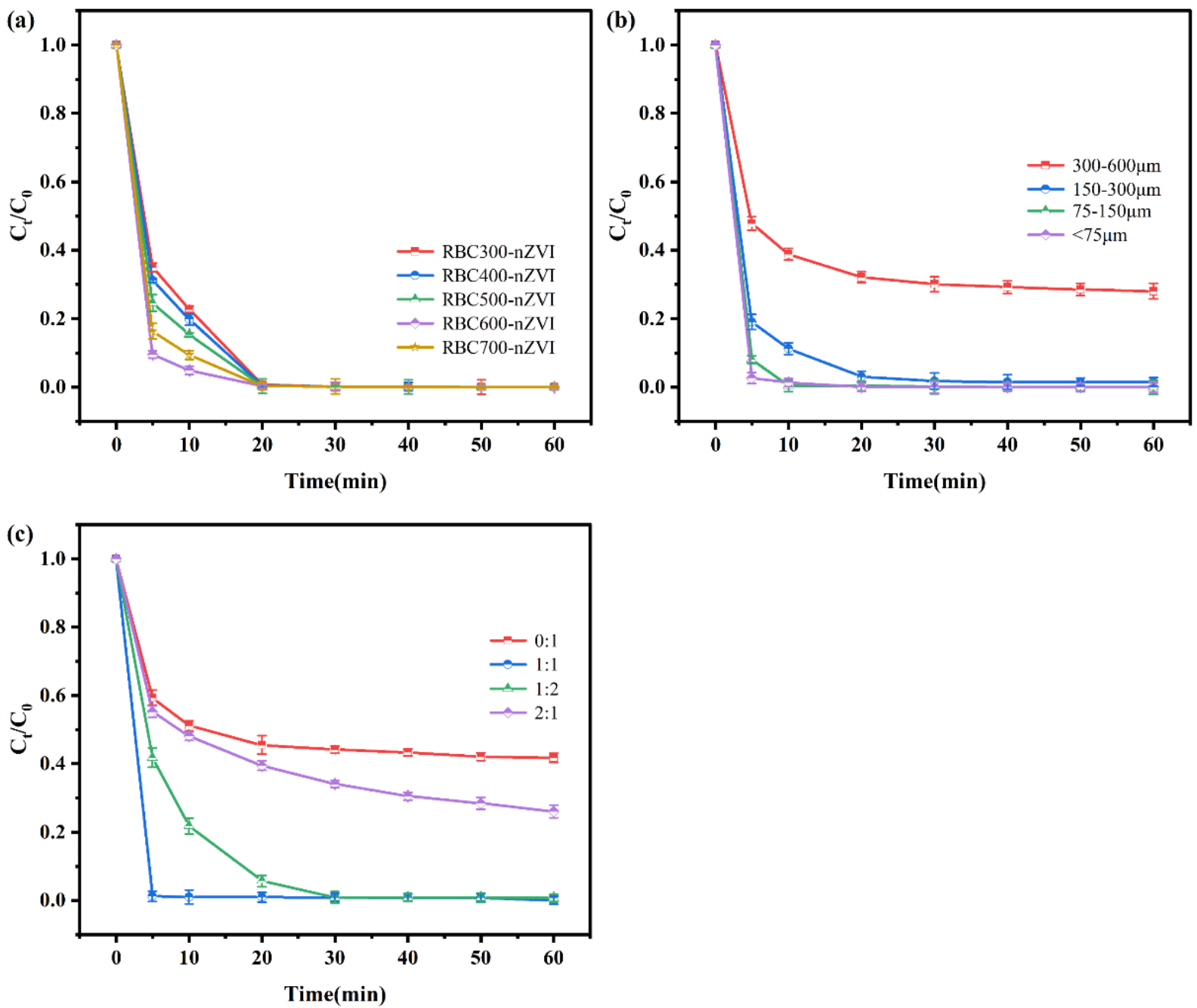

Figure 5. The removal of Cr(IV) by nZVI loaded with RBC600 prepared at different pyrolysis temperatures (a); NZVI loaded with different particle size RBC600 (b); different mass ratios of RBC600 to nZVI (c). Vertical bars denote the standard deviations of the means $(n=2)$. Experimental conditions: initial $\mathrm{Cr}(\mathrm{IV})$ concentration $20 \mathrm{mg} / \mathrm{L}, \mathrm{RBC}-\mathrm{nZVI}$ dosage $1 \mathrm{~g} / \mathrm{L}$, $\mathrm{T}=25^{\circ} \mathrm{C}, \mathrm{pH}=5$.

The RBC600 with a particle size of $<150$ microns was selected to study the influence of the mass ratio of RBC600/nZVI on the $\mathrm{Cr}(\mathrm{VI})$ elimination by RBC600-nZVI. The divergent mass ratios of RBC600/nZVI (0:1, 1:1, 1:2, and 2:1 ratio) highly influenced the removal of $\mathrm{Cr}(\mathrm{VI})$ by RBC600-nZVI (Figure 5c). The results illustrated that the efficacy of RBC600-nZVI $(1: 1)(100 \%)$ for the alleviation of $\mathrm{Cr}(\mathrm{VI})$ was approximately $41.74 \%$ higher than that of bare nZVI (RBC600:nZVI $=0: 1)(58.26 \%)$ and $26.08 \%$ higher than that of the RBC600-nZVI (2:1) (73.92\%). Noticeably, nearly $100 \%$ of $\mathrm{Cr}(\mathrm{VI})$ alleviation was achieved by RBC600-nZVI 
(1:1) during the first $5 \mathrm{~min}$. Moreover, it is noteworthy herein that both the reaction rate and elimination efficiency of RBC600-nZVI (1:1) for $\mathrm{Cr}(\mathrm{VI})$ were greater than the other mass ratio complexes with the equal mass of $n Z V I(500 \mathrm{mg} / \mathrm{L})$. These results show that nZVI presence on the surface of biochar certainly plays a pivotal role in the alleviation of $\mathrm{Cr}(\mathrm{VI})$ [39]. When using nZVI alone, severe agglomeration (Figure 2a,b) hindered the reaction, resulting in the decreased reducing potential of the iron particles. When the content of RBC600 was high, BC blocked the active site of nZVI. When the mass ratio of BC/Fe was 1:1, nZVI particles were uniformly dispersed on the surface of RBC600, which had the highest reduction/charge transfer reactivity. Therefore, the subsequent experiment used mass ratios of RBC600 to $\mathrm{nZVI}=1: 1$.

\subsection{Effects of Physicochemical Factors on Cr(VI) Removal}

The RBC600-nZVI displayed prominent results for $\mathrm{pH}$-dependent removal of $\mathrm{Cr}(\mathrm{VI})$ (Figure 6a). The $\mathrm{Cr}(\mathrm{VI})$ removal dramatically decreased $(p<0.05)$ with the increment of initial $\mathrm{pH}(3,5,6,7$, and 9). This result is in accordance with the earlier studies $[26,27,40]$. The results indicated that a lower $\mathrm{pH}$ is more appropriate for the alleviation of $\mathrm{Cr}(\mathrm{VI})$ through implementing RBC600-nZVI. When the $\mathrm{pH}$ was 3, the removal rate was close to $100 \%$ at $5 \mathrm{~min}$. Studies have shown that $\mathrm{pH}$ impacts the $\mathrm{Cr}(\mathrm{VI})$ existence [41]. The predominant forms of $\mathrm{Cr}(\mathrm{VI})$ were $\mathrm{HCrO}_{4}{ }^{-}, \mathrm{Cr}_{2} \mathrm{O}_{7}{ }^{2-}$, and $\mathrm{CrO}_{4}{ }^{2-}$ between $\mathrm{pH} 2.0$ and 8.0; the acidic environment facilitates the removal [42]. In addition, with respect to $\mathrm{pH}$, $\mathrm{nZVI}$ is more likely to release reducing electrons under acidic conditions, supporting $\mathrm{Cr}(\mathrm{VI})$ elimination and conversion to a lower valent state [43]. Increasing $\mathrm{pH}$ further enhanced $\mathrm{Fe}(\mathrm{III}) / \mathrm{Cr}$ (III) hydroxide co-precipitating onto nZVI reactive sites, hence decreasing $\mathrm{Cr}(\mathrm{VI})$ removal. The hydroxides and oxide layers are readily developed on the surfaces of iron nanoparticles under alkaline conditions, which impedes the $\mathrm{Cr}$ (VI) elimination through iron nanoparticles [44]. It is different from the literature that the treatment effect was still $80 \%$ at $\mathrm{pH} 9$ in the present study. Since the difference between the treatment's effect at pH 5 and 3 was not significant $(p>0.05)$, a pH of 5 was selected for subsequent experiments.

Temperature is also an imperative factor for the reaction of systems. The production of RBC600-nZVI was intended to react with a volume of $50 \mathrm{~mL}$ of $20 \mathrm{mg} / \mathrm{L}$ aqueous $\mathrm{Cr}(\mathrm{VI})$ solution at divergent gradients of temperatures (i.e., 25, 35, 45, and $55{ }^{\circ} \mathrm{C}$ ), which demonstrated varied removal rates (Figure 6b). The removal efficiency increased continuously with the increase of temperature raised from 25 to $55{ }^{\circ} \mathrm{C}$. The removal rate of $45(100 \%)$ and $55(100 \%)$ at 5 min was significantly $(p<0.05)$ higher than that of $25(80.96 \%)$ and $35(91.05 \%)$. This was possibly due to higher temperature conducive to enhance the diffusion $\mathrm{Cr}(\mathrm{VI})$ ions, thus improving the contact possibility of $\mathrm{Cr}(\mathrm{VI})$ ions to the adsorption pockets [45]. In addition, the reduction reaction of $\mathrm{Cr}(\mathrm{VI})$ by $\mathrm{nZVI}$ is an endothermic process [46], and the increase in temperature enables the electron transfer from nZVI to $\mathrm{Cr}(\mathrm{VI})$ [47].

The initial concentration of metals also has a great influence on their removal through treatments from the system. In the present study, we investigated the effects of initial $\mathrm{Cr}(\mathrm{VI})$ concentrations ranging from 10 to $80 \mathrm{mg} / \mathrm{L}$, on its alleviation from aqueous solution. The initial $\mathrm{Cr}$ (VI) concentrations of 10 and $20 \mathrm{mg} / \mathrm{L}$ were completely removed within $60 \mathrm{~min}$ (Figure 6c). The removal efficiency for $\mathrm{Cr}(\mathrm{VI})$ decreased with the increased initial concentration of $\mathrm{Cr}(\mathrm{VI})$. This was primarily due to the limitation of active sites of a certain amount of nZVI particles. With the increase of the initial concentration of $\mathrm{Cr}(\mathrm{VI})$, the available active sites are also occupied. Moreover, the reaction of $\mathrm{Cr}(\mathrm{VI})$ with nZVI became more intensive as the concentration increased, leading to the fast formation of $\mathrm{Cr}-\mathrm{Fe}$ inactivating layer, thus enclosing the nZVI and blocking the electron transfer. The compound/hydroxide passivation layer inhibited the reaction. 

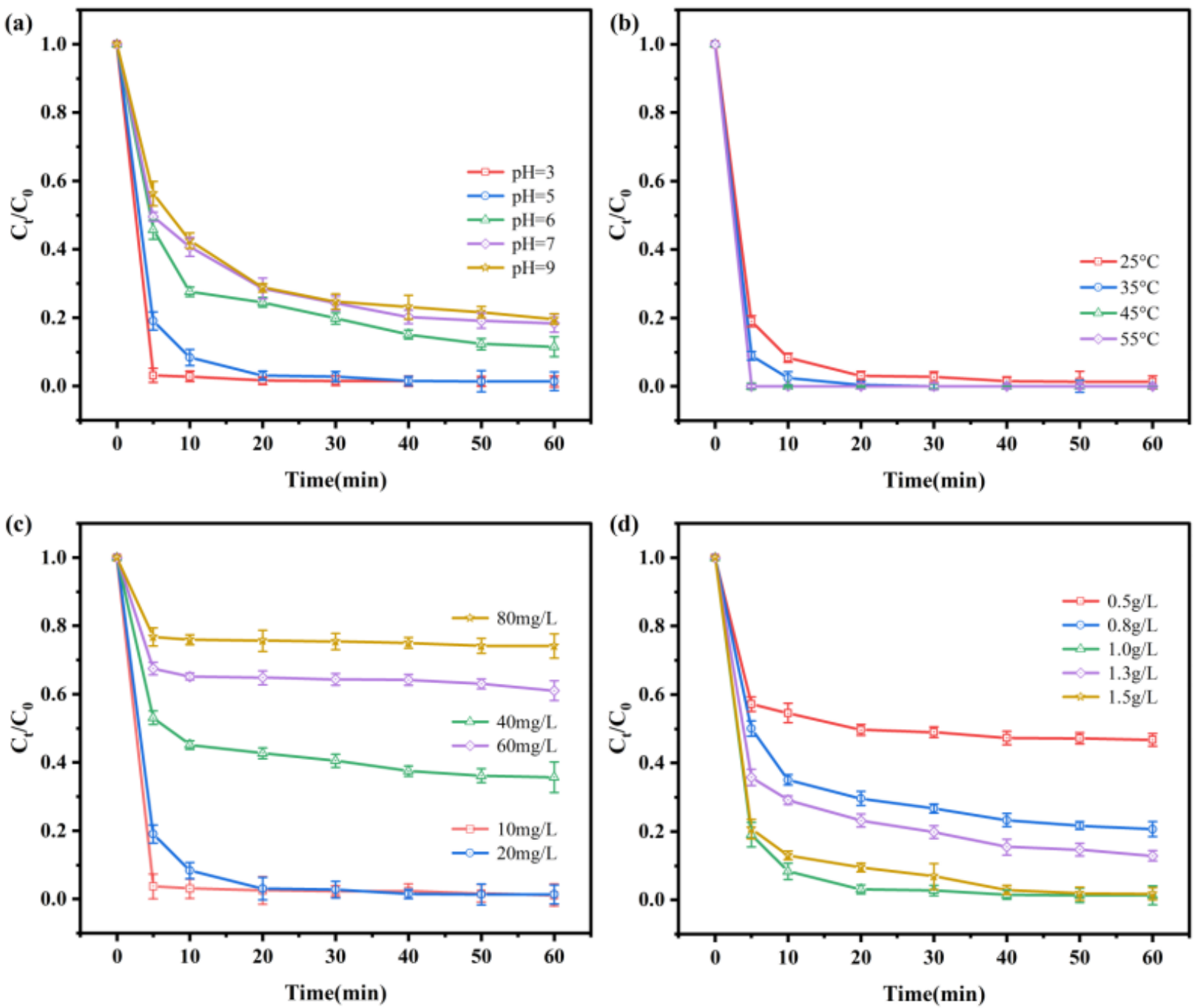

Figure 6. $\mathrm{Cr}(\mathrm{VI})$ removal at various $\mathrm{pH}$ values (a); at various temperature (b); at various initial concentration (c); at various dosages (d). Experimental conditions: initial $\mathrm{Cr}(\mathrm{IV})$ concentration $20 \mathrm{mg} / \mathrm{L}, \mathrm{RBC}-\mathrm{nZVI}$ dosage $1 \mathrm{~g} / \mathrm{L}, \mathrm{T}=25^{\circ} \mathrm{C}, \mathrm{pH}=5$. Vertical bars denote the standard deviations of the means $(n=2)$.

Application rate (dose) of RBC600-nZVI markedly influenced the removal of $\mathrm{Cr}$ (VI) from the aqueous solution. The effect of RBC600-nZVI dosage on its capability for the $\mathrm{Cr}(\mathrm{VI})$ removal was examined in the range of $0.5-1.5 \mathrm{~g} / \mathrm{L}$. Results demonstrated that the removal efficiency of $1 \mathrm{~g} / \mathrm{L}$ and $1.5 \mathrm{~g} / \mathrm{L}$ was significantly $(p<0.05)$ higher than $0.5 \mathrm{~g} / \mathrm{L}$, $0.8 \mathrm{~g} / \mathrm{L}$, and $1.3 \mathrm{~g} / \mathrm{L}$ (Figure $6 \mathrm{~d}$ ). It can be stated that as the application dose increased, the removal capacity of RBC600-nZVI for $\mathrm{Cr}(\mathrm{VI})$ alleviation increased obviously, except for $1.3 \mathrm{~g} / \mathrm{L}$. This was mainly due to the increased application dose of RBC600-nZVI that increased the total available active sites for $\mathrm{Cr}(\mathrm{VI})$. Taken together, $1 \mathrm{~g} / \mathrm{L}$ was the best choice for the removal of $\mathrm{Cr}(\mathrm{VI})$ in the present study.

\subsection{Removal Mechanism}

The RBC600-nZVI substantially removed $\mathrm{Cr}(\mathrm{VI})$ from the aqueous solution. Several factors, processes, and mechanisms attributed to the removal of $\mathrm{Cr}(\mathrm{VI})$, mainly galvanic interactions, electrostatic attraction, and precipitation redox [5]. To probe and validate the removal mechanisms of $\mathrm{Cr}(\mathrm{VI})$, both XRD and XPS were used in order to examine the reaction products.

To understand the removal mechanism of $\mathrm{Cr}(\mathrm{VI})$, the XPS was employed to investigate the chemical transformations of RBC600-nZVI prior and post-reaction. The full scan of the XPS spectra illustrated obvious results for the RBC600-nZVI before and after the reactions 
and changes in the atomic ratio of the elements on their surface (Figure $7 \mathrm{a}, \mathrm{b})$. After the reaction with $\mathrm{Cr}(\mathrm{VI})$, the proportions of iron and oxygen increased by 5.69 and 3.97\%, respectively. Reduction of carbon content indicates that RBC600 participates in the removal of $\mathrm{Cr}$ (VI) to a certain extent, which may be reduction or complexation. The research has demonstrated that the functional groups, for instance, phenolic and - $\mathrm{COOH}$ groups, and $\mathrm{C}$ matrix of biochar participated in $\mathrm{Cr}(\mathrm{VI})$ reduction [48]. The changes in the content of $\mathrm{C}-\mathrm{C}$, $\mathrm{C}-\mathrm{O}, \mathrm{C}=\mathrm{O}, \mathrm{O}-\mathrm{C}=\mathrm{O}$, and $\mathrm{C}-\mathrm{COOR}$ (Figure $7 \mathrm{c}, \mathrm{d}$ ) further indicates that a complex reaction may have occurred. The increase in the atomic ratio of iron indicates that the zero-valent iron nucleus is involved in the reaction. After the reaction, the $\mathrm{Fe}^{0}$ peaks disappeared (Figure 7e,f), suggesting that nZVI participated in the reaction and was oxidized by $\mathrm{Cr}(\mathrm{VI})$. Additionally, Fe(II) content decreased by $4.1 \%$, while Fe(III) contents increased by $11.83 \%$, proving that $\mathrm{Fe}(\mathrm{II})$ contributed to the reaction and oxidized to produce $\mathrm{Fe}(\mathrm{III})$. A new peak appeared at a binding energy of $580 \mathrm{eV}$, conjecturing that $\mathrm{Cr}$ uptake was carried out on the RBC600-nZVI surface [49]. The peaks of 576.6 and $587.2 \mathrm{eV}$ matched to $\mathrm{Cr}(\mathrm{III})$, while the peaks of 578.0 and $587.9 \mathrm{eV}$ were related to $\mathrm{Cr}(\mathrm{VI})$ (Figure $7 \mathrm{~g}$ ). The area ratios of $\mathrm{Cr}(\mathrm{III})$ and $\mathrm{Cr}(\mathrm{VI})$ were 69.1 and $30.9 \%$, respectively, representing that both reduction and adsorption carried out during the reaction, however, the reduction process was dominant. The peaks at 577.0 and $589.0 \mathrm{eV}$ showed that $\mathrm{Cr}(\mathrm{III})$ existed in the form of $\left(\mathrm{Fe}_{\mathrm{x}} \mathrm{Cr}_{1-\mathrm{x}}\right)(\mathrm{OH})_{3}$ or Fe $(\mathrm{OH})_{3}-\mathrm{Cr}(\mathrm{OH})_{3}[50]$.

To further investigate the removal mechanism of $\mathrm{Cr}(\mathrm{VI})$, the XRD technique was employed to identify the chemical transformations of RBC600-nZVI. The distinctive changes in RBC600-nZVI were observed post-reaction with $\mathrm{Cr}(\mathrm{VI})$ (Figure 7h). The XRD analysis for the RBC600-nZVI prior to the reaction with $\mathrm{Cr}(\mathrm{VI})$ displayed a distinct characteristic peak of $\mathrm{Fe}^{0}$, which disappeared dramatically after the reaction. The XRD analysis for the RBC600-nZVI after reaction showed the existence of $\mathrm{K}_{2} \mathrm{CrO}_{4}, \mathrm{Cr}_{2} \mathrm{O}_{3}, \mathrm{CrO}(\mathrm{OH})$, and $\mathrm{FeCr}_{2} \mathrm{O}_{4}$, which were not distinguished in the sample prior to the reaction occurring. The presence of $\mathrm{Cr}(\mathrm{III}), \mathrm{Fe}(\mathrm{III})$, and Fe(II) in RBC600-nZVI after reaction validated the happening of redox reaction between $\mathrm{Cr}(\mathrm{VI})$ ions and $\mathrm{nZVI}$ particles. Hence, it can be established that the reduction of $\mathrm{Cr}(\mathrm{VI})$ to $\mathrm{Cr}(\mathrm{III})$ was carried out in the form of $\mathrm{Cr}_{2} \mathrm{O}_{3}, \mathrm{CrO}(\mathrm{OH})$, and $\mathrm{FeCr}_{2} \mathrm{O}_{4}$ (Figure 7h). Moreover, the oxidation reaction changed the nZVI to $\mathrm{FeO}, \mathrm{FeO}(\mathrm{OH})$, and $\mathrm{Fe}_{2} \mathrm{O}_{3}$. It is plausible that the results obtained through various techniques employed to characterize RBC600-nZVI evidently revealed that RBC600-nZVI was involved in the removal and reduction of $\mathrm{Cr}(\mathrm{VI})$ [23].

The functional analysis of RBC600-nZVI composite revealed the potential mechanisms for $\mathrm{Cr}(\mathrm{VI})$ elimination from aqueous solution. The adsorption, reduction, and sedimentation took place simultaneously and cooperated with each other for the removal of $\mathrm{Cr}(\mathrm{VI})$ (Figure 8). The main reactions attributed in the process are as follows: (1) Adsorption: The adsorption of $\mathrm{Cr}(\mathrm{VI})$ oxyanions onto biochar carrier and onto oxide layers existent on the surface of nZVI. (2) Reduction: The majority of the adsorbed $\mathrm{Cr}(\mathrm{VI})$ species was simultaneously reduced to $\mathrm{Cr}$ (III) by $\mathrm{Fe}^{0}$ and $\mathrm{Fe}$ (II)-bearing secondary minerals coated on $\mathrm{Fe}^{0}$. In addition, $\mathrm{Fe}(\mathrm{II})$ dissolved by $\mathrm{Fe}^{0}$ oxidation $\left(\mathrm{Fe}^{0}\right.$ corrosion) could still react with $\mathrm{Cr}(\mathrm{VI})$. (3) Co-precipitation: As the nZVI was oxidized, the $\mathrm{pH}$ of the solution progressively increased and $\mathrm{OH}^{-}$aggregated, and $\mathrm{Cr}$ (III) combined with a large amount of $\mathrm{OH}^{-}$induced during the reaction to form alloy-like $\mathrm{Cr}$ (III)-Fe(III) hydroxide and fixed in nZVI. Consequently, in the present scenario of the reaction system, $\mathrm{Cr}(\mathrm{VI})$ can be efficiently eliminated due to the synergistic effects of RBC600 and nZVI. 


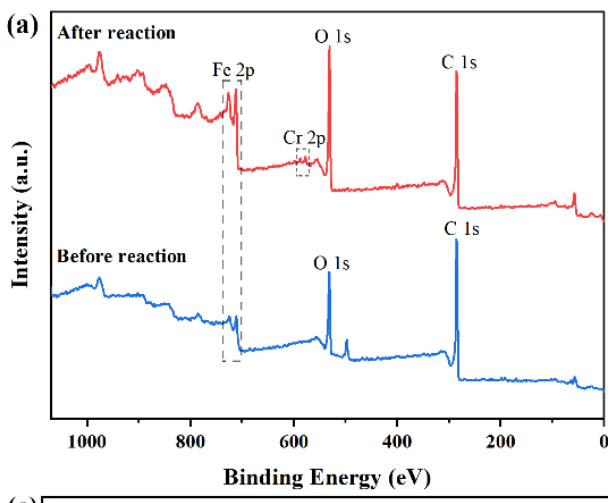

(b)
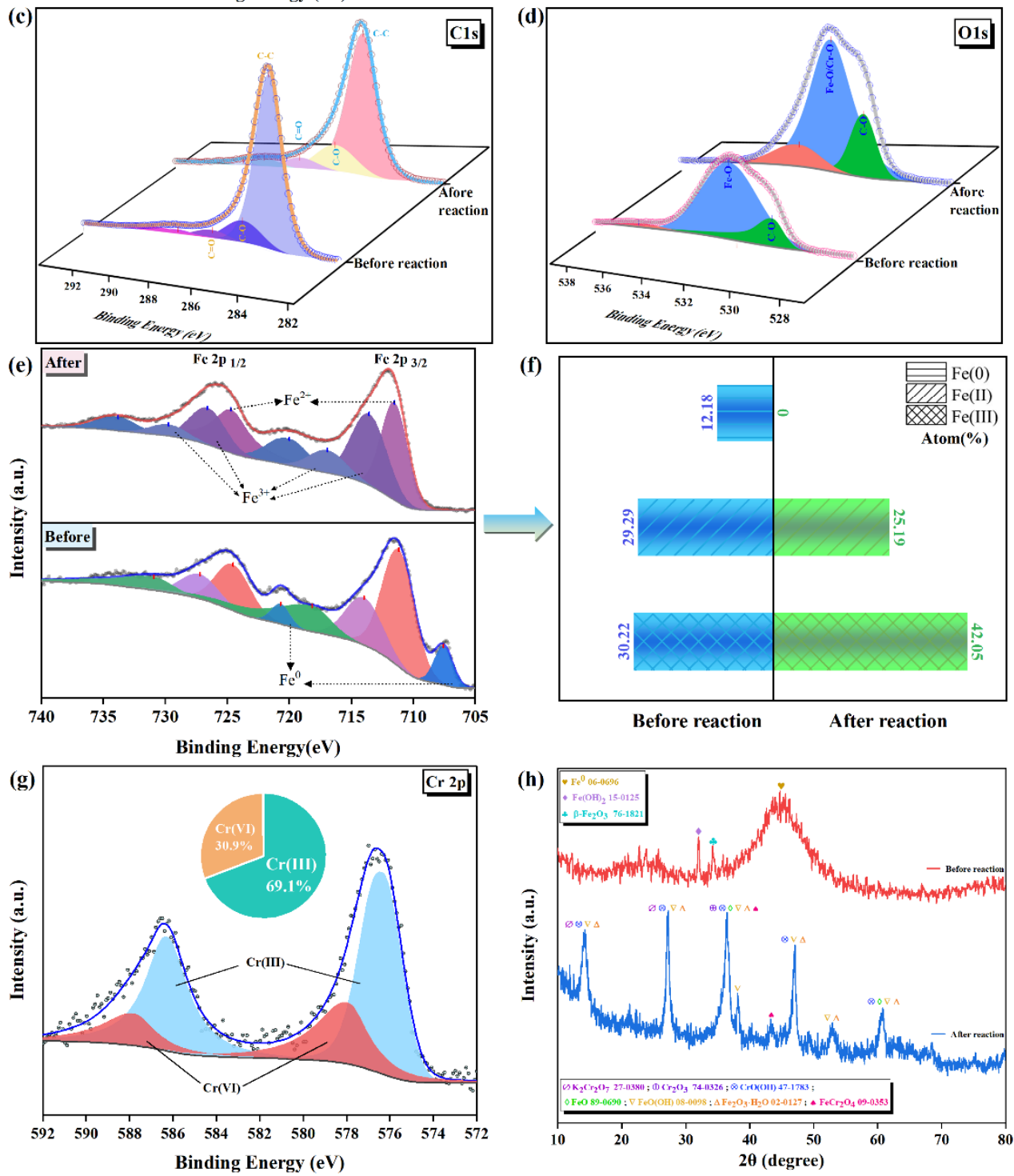

Figure 7. XPS spectra of RBC600-nZVI prior and post reactions with $\mathrm{Cr}(\mathrm{VI})$. (a) The full survey, (b) Content change of the surface atomic ratio of RBC600-nZVI before and after reaction with $\mathrm{Cr}(\mathrm{VI})$; (c) $\mathrm{C}$ 1s (d) $\mathrm{O}$ 1s and (e) Fe 2p binding state gradients; (f) The change of the specific content of iron in various valence states before and after the reaction of RBC600-nZVI with $\mathrm{Cr}(\mathrm{VI})$; (g) XPS spectra of $\mathrm{Cr} 2 \mathrm{p}$ after reaction with $\mathrm{Cr}(\mathrm{VI})$; (h) The XRD analysis of RBC600-nZVI before and after reaction with $\mathrm{Cr}(\mathrm{VI})$. 


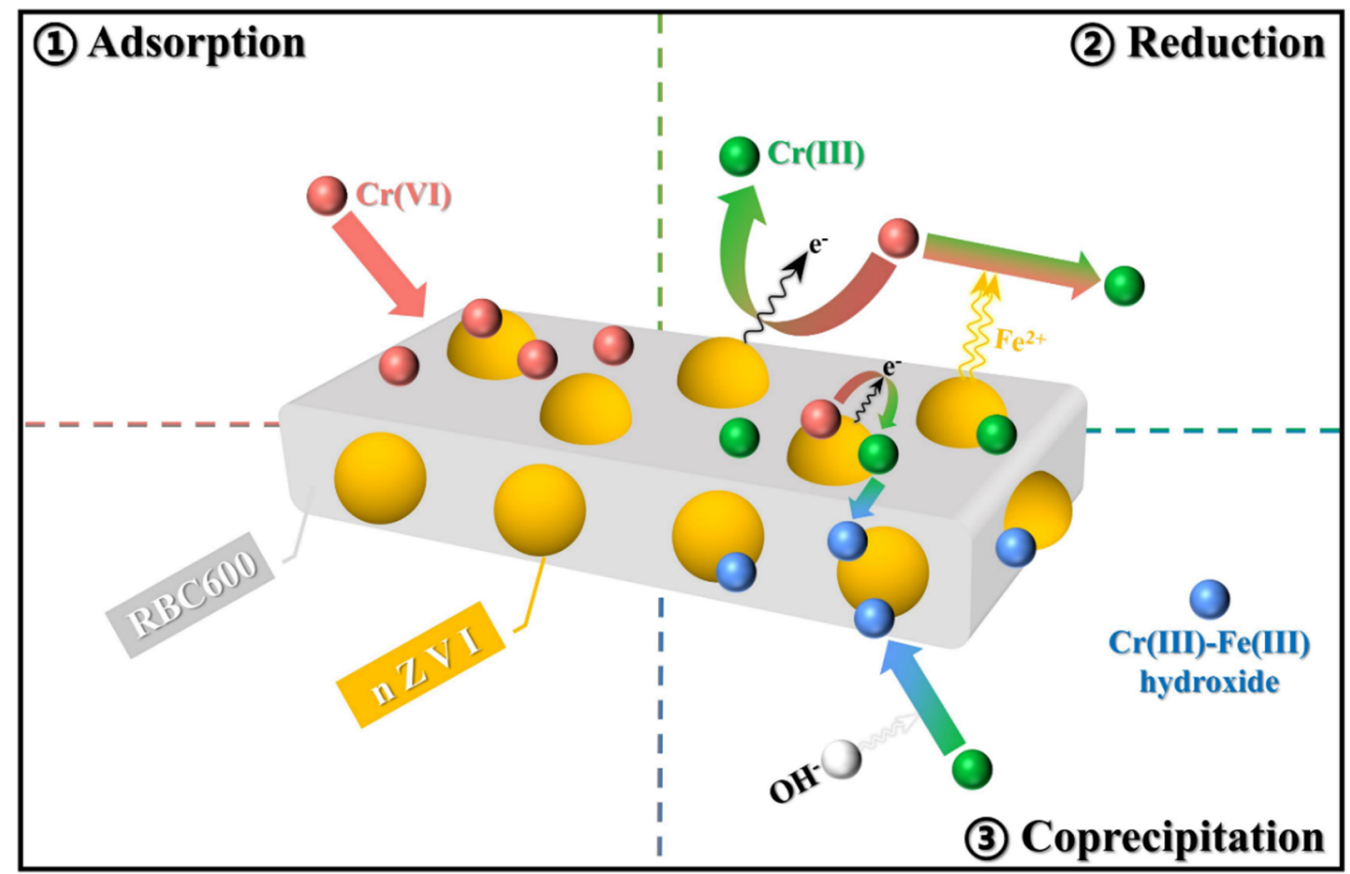

Figure 8. Proposed adsorption mechanisms of Cr(VI) by RBC600-nZVI.

\section{Conclusions}

In the present study, we successfully prepared a nano-zero-valent iron (nZVI) supported by ramie biochar (RBC600-nZVI). The RBC600-nZVI displayed excellent Cr(VI) elimination efficiency from the aqueous solution. The nZVI was evenly dispersed and had a smaller particle size. The nZVI supported by RBC significantly improved the reaction efficiency and removal capacity for $\mathrm{Cr}(\mathrm{VI})$. The XPS and XRD analysis proved that the removal mechanism was mainly chemical reduction, with synergistic adsorption and complexation. Further research is suggested for using various types of biochar produced at different temperatures.

Author Contributions: Conceptualization, X.T. and Q.-A.P.; methodology, X.T.; software, J.Y.; validation, Y.C., B.W. and Q.-A.P.; formal analysis, M.S.; investigation, X.T.; resources, X.T.; data curation, J.Y.; writing—original draft preparation, X.T.; writing—review and editing, M.S. and Q.-A.P.; visualization, X.T.; supervision, Q.-A.P.; project administration, Q.-A.P.; funding acquisition, Q.-A.P. All authors have read and agreed to the published version of the manuscript.

Funding: This research was funded by the Science and Technology Research Project in Education Bureau of Hubei, China (No: B2018061).

Institutional Review Board Statement: Not applicable.

Informed Consent Statement: Not applicable.

Data Availability Statement: The data presented in this study are available on request from the corresponding author.

Acknowledgments: This research work was supported by the Textile Printing and Dyeing of Clean Production Engineering Research Centre of the Ministry of Education, China.

Conflicts of Interest: The authors declare no conflict of interest.

\section{References}

1. Wang, Y.; Yu, L.; Wang, R.; Wang, Y.; Zhang, X. A novel cellulose hydrogel coating with nanoscale Fe0 for Cr(VI) adsorption and reduction. Sci. Total Environ. 2020, 726, 138625. [CrossRef]

2. Jia, X.; Zhang, Y.; He, Z.; Chang, F.; Zhang, H.; Wågberg, T.; Hu, J. Mesopore-rich badam-shell biochar for efficient adsorption of Cr (VI) from aqueous solution. J. Environ. Chem. Eng. 2021, 9, 105634. [CrossRef] 
3. He, X.; Li, P. Surface water pollution in the middle Chinese Loess Plateau with special focus on hexavalent chromium (Cr 6+): Occurrence, sources and health risks. Expo. Health 2020, 12, 385-401. [CrossRef]

4. Gan, Y.; Huang, X.; Li, S.; Liu, N.; Li, Y.C.; Freidenreich, A.; Wang, W.; Wang, R.; Dai, J. Source quantification and potential risk of mercury, cadmium, arsenic, lead, and chromium in farmland soils of Yellow River Delta. J. Clean. Prod. 2019, 221, 98-107. [CrossRef]

5. Yang, C.; Ge, C.; Li, X.; Li, L.; Wang, B.; Lin, A.; Yang, W. Does soluble starch improve the removal of Cr(VI) by nZVI loaded on biochar? Ecotoxicol. Environ. Saf. 2021, 208, 111552. [CrossRef] [PubMed]

6. Dong, H.; Deng, J.; Xie, Y.; Zhang, C.; Jiang, Z.; Cheng, Y.; Hou, K.; Zeng, G. Stabilization of nanoscale zero-valent iron (nZVI) with modified biochar for Cr (VI) removal from aqueous solution. J. Hazard. Mater. 2017, 332, 79-86. [CrossRef]

7. Lv, D.; Zhou, J.; Cao, Z.; Xu, J.; Liu, Y.; Li, Y.; Yang, K.; Lou, Z.; Lou, L.; Xu, X. Mechanism and influence factors of chromium (VI) removal by sulfide-modified nanoscale zerovalent iron. Chemosphere 2019, 224, 306-315. [CrossRef] [PubMed]

8. Yang, D.; Wang, L.; Li, Z.; Tang, X.; He, M.; Yang, S.; Liu, X.; Xu, J. Simultaneous adsorption of Cd(II) and As(III) by a novel biochar-supported nanoscale zero-valent iron in aqueous systems. Sci. Total Environ. 2020, 708, 134823. [CrossRef] [PubMed]

9. Chen, X.; Li, X.; Xu, D.; Yang, W.; Bai, S. Application of nanoscale zero-valent iron in hexavalent chromium-contaminated soil: A review. Nanotechnol. Rev. 2020, 9, 736-750. [CrossRef]

10. Hou, S.; Wu, B.; Peng, D.; Wang, Z.; Wang, Y.; Xu, H. Remediation performance and mechanism of hexavalent chromium in alkaline soil using multi-layer loaded nano-zero-valent iron. Environ. Pollut. 2019, 252, 553-561. [CrossRef]

11. Li, P.; Yu, J.; Huangfu, Z.; Chang, J.; Zhong, C.; Ding, P. Applying modified biochar with nZVI/nFe $3 \mathrm{O}_{4}$ to immobilize Pb in contaminated soil. Environ. Sci. Pollut. Res. 2020, 27, 24495-24506. [CrossRef] [PubMed]

12. Wei, G.; Zhang, J.; Luo, J.; Xue, H.; Huang, D.; Cheng, Z.; Jiang, X. Nanoscale zero-valent iron supported on biochar for the highly efficient removal of nitrobenzene. Front. Environ. Sci. Eng. 2019, 13, 61. [CrossRef]

13. Shaaban, M.; Van Zwieten, L.; Bashir, S.; Younas, A.; Núñez-Delgado, A.; Chhajro, M.A.; Kubar, K.A.; Ali, U.; Rana, M.S.; Mehmood, M.A.; et al. A concise review of biochar application to agricultural soils to improve soil conditions and fight pollution. J. Environ. Manag. 2018, 228, 429-440. [CrossRef]

14. Lyu, H.; Tang, J.; Cui, M.; Gao, B.; Shen, B. Biochar/iron (BC/Fe) composites for soil and groundwater remediation: Synthesis, applications, and mechanisms. Chemosphere 2020, 246, 125609. [CrossRef] [PubMed]

15. Jiang, W.; Song, Y.; Liu, S.; Ben, H.; Zhang, Y.; Zhou, C.; Han, G.; Ragauskas, A.J. A green degumming process of ramie. Ind. Crop. Prod. 2018, 120, 131-134. [CrossRef]

16. Mu, L.; Cai, M.; Wang, Z.; Liu, J.; Liu, T.; Wanapat, M.; Huang, B. Assessment of ramie leaf (Boehmeria nivea L. gaud) as an animal feed supplement in PR China. Trop. Anim. Health Prod. 2020, 52, 115-121. [CrossRef]

17. Chen, X.; Fan, G.; Li, H.; Li, Y.; Zhang, R.; Huang, Y.; Xu, X. Nanoscale zero-valent iron particles supported on sludge-based biochar for the removal of chromium (VI) from aqueous system. Environ. Sci. Pollut. Res. 2021. [CrossRef] [PubMed]

18. Wang, W.-D.; Ma, H.-T.; Lin, W.; Sun, P.; Zhang, L.-K.; Han, J.-H. Trametes suaveolens-derived biochar loaded on nanoscale zero-valent iron particles for the adsorption and reduction of $\mathrm{Cr}(\mathrm{VI})$. Int. J. Environ. Sci. Technol. 2021, 1-14. [CrossRef]

19. Zhang, Y.; Jiao, X.; Liu, N.; Lv, J.; Yang, Y. Enhanced removal of aqueous Cr(VI) by a green synthesized nanoscale zero-valent iron supported on oak wood biochar. Chemosphere 2020, 245, 125542. [CrossRef]

20. Shu, Y.R.; Ji, B.; Cui, B.H.; Shi, Y.T.; Wang, J.; Hu, M.; Luo, S.; Guo, D. Almond Shell-Derived, Biochar-Supported, Nano-ZeroValent Iron Composite for Aqueous Hexavalent Chromium Removal: Performance and Mechanisms. Nanomaterials 2020, 10, 198. [CrossRef]

21. Ma, F.; Philippe, B.; Zhao, B.; Diao, J.; Li, J. Simultaneous adsorption and reduction of hexavalent chromium on biochar-supported nanoscale zero-valent iron (nZVI) in aqueous solution. Water Sci. Technol. 2020, 82, 1339-1349. [CrossRef] [PubMed]

22. Khandelwal, N.; Behera, M.P.; Rajak, J.K.; Darbha, G.K. Biochar-nZVI nanocomposite: Optimization of grain size and Fe(0)loading, application and removal mechanism of anionic metal species from soft water, hard water and groundwater. Clean Technol. Environ. Policy 2020, 22, 1015-1024. [CrossRef]

23. Fan, Z.; Zhang, Q.; Gao, B.; Li, M.; Liu, C.; Qiu, Y. Removal of hexavalent chromium by biochar supported nZVI composite: Batch and fixed-bed column evaluations, mechanisms, and secondary contamination prevention. Chemosphere 2019, $217,85-94$. [CrossRef]

24. Diao, Z.H.; Du, J.J.; Jiang, D.; Kong, L.J.; Huo, W.Y.; Liu, C.M.; Wu, Q.H.; Xu, X.R. Insights into the simultaneous removal of Cr ${ }^{6+}$ and $\mathrm{Pb}^{2+}$ by a novel sewage sludge-derived biochar immobilized nanoscale zero valent iron: Coexistence effect and mechanism. Sci. Total. Environ. 2018, 642, 505-515. [CrossRef] [PubMed]

25. Qian, L.; Zhang, W.; Yan, J.; Han, L.; Chen, Y.; Ouyang, D.; Chen, M. Nanoscale zero-valent iron supported by biochars produced at different temperatures: Synthesis mechanism and effect on $\mathrm{Cr}(\mathrm{VI})$ removal. Environ. Pollut. 2017, 223, 153-160. [CrossRef]

26. Shang, J.G.; Zong, M.Z.; Yu, Y.; Kong, X.R.; Du, Q.; Liao, Q.J.H. Removal of chromium (VI) from water using nanoscale zerovalent iron particles supported on herb-residue biochar. J. Environ. Manag. 2017, 197, 331-337. [CrossRef] [PubMed]

27. Zhang, S.H.; Wu, M.F.; Tang, T.T.; Xing, Q.J.; Peng, C.Q.; Li, F.; Liu, H.; Luo, X.B.; Zou, J.P.; Min, X.B.; et al. Mechanism investigation of anoxic Cr(VI) removal by nano zero-valent iron based on XPS analysis in time scale. Chem. Eng. J. 2018, 335, 945-953. [CrossRef]

28. Su, H.; Fang, Z.; Tsang, P.E.; Fang, J.; Zhao, D. Stabilisation of nanoscale zero-valent iron with biochar for enhanced transport and in-situ remediation of hexavalent chromium in soil. Environ. Pollut. 2016, 214, 94-100. [CrossRef] 
29. Chen, G.-Q.; Zhang, W.-J.; Zeng, G.-M.; Huang, J.-H.; Wang, L.; Shen, G.-L. Surface-modified Phanerochaete chrysosporium as a biosorbent for $\mathrm{Cr}(\mathrm{VI})$-contaminated wastewater. J. Hazard. Mater. 2011, 186, 2138-2143. [CrossRef]

30. Wang, Y.; Yu, L.; Wang, R.; Wang, Y.; Zhang, X. Microwave catalytic activities of supported perovskite catalysts MOx/LaCo0. 5Cu0. 5O3@ CM (M = Mg, Al) for salicylic acid degradation. J. Colloid Interface Sci. 2020, 564, 392-405. [CrossRef]

31. Bhatti, Z.A.; Qureshi, K.; Maitlo, G.; Ahmed, S. Study of PAN fiber and iron ore adsorbents for arsenic removal. Civ. Eng. J. 2020, 6, 548-562. [CrossRef]

32. Zhou, L.; Zhuang, W.-Q.; De Costa, Y.; Xia, S. Potential effects of suspended TiO2 nanoparticles on activated sludge floc properties in membrane bioreactors. Chemosphere 2019, 223, 148-156. [CrossRef] [PubMed]

33. Ahmed, M.B.; Zhou, J.L.; Ngo, H.H.; Guo, W.; Chen, M. Progress in the preparation and application of modified biochar for improved contaminant removal from water and wastewater. Bioresour. Technol. 2016, 214, 836-851. [CrossRef] [PubMed]

34. Wan, Z.; Cho, D.-W.; Tsang, D.C.; Li, M.; Sun, T.; Verpoort, F. Concurrent adsorption and micro-electrolysis of Cr(VI) by nanoscale zerovalent iron/biochar/Ca-alginate composite. Environ. Pollut. 2019, 247, 410-420. [CrossRef]

35. Dickinson, M.; Scott, T.B.; Crane, R.A.; Riba, O.; Barnes, R.J.; Hughes, G.M. The effects of vacuum annealing on the structure and surface chemistry of iron:nickel alloy nanoparticles. J. Nanoparticle Res. 2010, 12, 2081-2092. [CrossRef]

36. Mu, Y.; Jia, F.L.; Ai, Z.H.; Zhang, L.Z. Iron oxide shell mediated environmental remediation properties of nano zero-valent iron. Environ. Sci. Nano 2017, 4, 27-45. [CrossRef]

37. Bae, S.; Collins, R.N.; Waite, T.D.; Hanna, K. Advances in Surface Passivation of Nanoscale Zerovalent Iron: A Critical Review. Environ. Sci. Technol. 2018, 52, 12010-12025. [CrossRef]

38. Li, M.; Shang, H.; Li, H.; Hong, Y.; Ling, C.; Wei, K.; Zhou, B.; Mao, C.; Ai, Z.; Zhang, L. Kirkendall Effect Boosts Phosphorylated nZVI for Efficient Heavy Metal Wastewater Treatment. Angew. Chem. Int. Ed. 2021, 60, 17115-17122. [CrossRef]

39. Lv, X.S.; Qin, X.F.; Wang, K.F.; Peng, Y.Y.; Wang, P.; Jiang, G.M. Nanoscale zero valent iron supported on MgAl-LDH-decorated reduced graphene oxide: Enhanced performance in $\mathrm{Cr}(\mathrm{VI})$ removal, mechanism and regeneration. J. Hazard. Mater. 2019, 373, 176-186. [CrossRef]

40. Wu, L.M.; Liao, L.B.; Lv, G.C.; Qin, F.X.; He, Y.J.; Wang, X.Y. Micro-electrolysis of Cr (VI) in the nanoscale zero-valent iron loaded activated carbon. J. Hazard. Mater. 2013, 254, 277-283. [CrossRef]

41. Cheng, Y.J.; Dong, H.R.; Hao, T.W. CaCO3 coated nanoscale zero-valent iron (nZVI) for the removal of chromium(VI) in aqueous solution. Sep. Purif. Technol. 2021, 257, 117967. [CrossRef]

42. Szabó, M.; Kalmár, J.; Ditrói, T.; Bellér, G.; Lente, G.; Simic, N.; Fábián, I. Equilibria and kinetics of chromium(VI) speciation in aqueous solution-A comprehensive study from $\mathrm{pH} 2$ to 11. Inorganica Chim. Acta 2018, 472, 295-301. [CrossRef]

43. Li, J.; Fana, M.J.; Li, M.; Liu, X. Cr(VI) removal from groundwater using double surfactant-modified nanoscale zero-valent iron (nZVI): Effects of materials in different status. Sci. Total Environ. 2020, 717, 137112. [CrossRef]

44. Zhou, S.; Li, Y.; Chen, J.; Liu, Z.; Wang, Z.; Na, P. Enhanced Cr(vi) removal from aqueous solutions using Ni/Fe bimetallic nanoparticles: Characterization, kinetics and mechanism. RSC Adv. 2014, 4, 50699-50707. [CrossRef]

45. Qiu, Y.; Zhang, Q.; Gao, B.; Li, M.; Fan, Z.X.; Sang, W.J.; Hao, H.; Wei, X. Removal mechanisms of Cr(VI) and Cr(III) by biochar supported nanosized zero-valent iron: Synergy of adsorption, reduction and transformation. Environ. Pollut. 2020, $265,115018$. [CrossRef]

46. Chang, D.Y.; Chen, T.H.; Liu, H.B.; Xi, Y.F.; Qing, C.S.; Xie, Q.Q. A new approach to prepare ZVI and its application in removal of Cr(VI) from aqueous solution. Chem. Eng. J. 2014, 244, 264-272. [CrossRef]

47. Liu, T.Y.; Zhao, L.; Tan, X.; Liu, S.J.; Li, J.J.; Qi, Y.; Mao, G.Z. Effects of physicochemical factors on Cr(VI) removal from leachate by zero-valent iron and alpha- $\mathrm{Fe}_{2} \mathrm{O}_{3}$ nanoparticles. Water Sci. Technol. 2010, 61, 2759-2767. [CrossRef]

48. Zhou, M.; Yang, X.; Sun, R.; Wang, X.; Yin, W.; Wang, S.; Wang, J. The contribution of lignocellulosic constituents to Cr(VI) reduction capacity of biochar-supported zerovalent iron. Chemosphere 2021, 263, 127871. [CrossRef]

49. Qian, L.; Shang, X.; Zhang, B.; Zhang, W.; Su, A.; Chen, Y.; Ouyang, D.; Han, L.; Yan, J.; Chen, M. Enhanced removal of Cr (VI) by silicon rich biochar-supported nanoscale zero-valent iron. Chemosphere 2019, 215, 739-745. [CrossRef] [PubMed]

50. Du, J.; Bao, J.; Lu, C.; Werner, D. Reductive sequestration of chromate by hierarchical FeS@ Fe0 particles. Water Res. 2016, 102, 73-81. [CrossRef] [PubMed] 